ISSN 0258-7122 (Print), 2408-8293 (Online)

Bangladesh J. Agril. Res. 41(1): 127-136, March 2016

\title{
EFFECT OF SOWING TIME AND VARIETY ON SEED GERMINATION AND VIGOUR INDEX OF WHEAT
}

\author{
MD. RAYHAN SHAHEB ${ }^{1}$, MD. NAZMUL ISLAM ${ }^{2}$ \\ M. SIDDIKUR RAHMAN ${ }^{3}$, AND ASHRATUN NESSA ${ }^{4}$
}

\begin{abstract}
Experiments were carried out in research field and laboratory of Seed Technology Division, Bangladesh Agricultural Research Institute, Gazipur during rabi season of 2008-09 and 2009-10 to find out the effect of sowing time and variety on seed germination and vigour index of wheat after harvest of the crop. There were two sets of treatments, comprising a) three dates of sowing viz. 20 November, 5 December and 20 December; and b) three varieties viz. 'Bijoy', 'Sufi' and 'Prodip'. Split plot design and complete block design were followed in field and laboratory experiments, respectively. Results revealed that the highest seed germination $93.33 \%$ was recorded in 'Prodip' sown on 20 December, 2008 and 'Bijoy' sown on 5 December, 2009. However, all the varieties showed more than $83 \%$ seed germination at all dates of sowing of wheat. The highest vigour indices, 1.53 and 1.41 were found in the seeds of 'Sufi' sown on 20 November in both the years of 2008 and 2009, respectively.
\end{abstract}

Keywords: wheat, sowing time, variety, seed germination, vigour index.

\section{Introduction}

Wheat is the second most important food grains in Bangladesh. Rice and wheat altogether occupied over $80 \%$ of the total cropped area. In 2010-11, the total area and productions of wheat in the country were 3.74 lac hectares and 9.72 lac. MT (BBS, 2011). Quality seed is considered as the basic critical input which directly affects yield and could increase crop production by 10-15\% (Mondal, 2005), while BADC (2012) reported that quality seed alone can contribute to the increase of yield by $15-20 \%$. In order to maintain purity and quality of seeds several steps should be undertaken. Sowing in optimum time, application of balanced fertilizer and irrigation in proper time, rouging and weeding are essential for successful seed production. Greven et al. (2004) reported that timing of harvest is an important factor since both seed immaturity and weathering reduce seed quality. Kumar et al. (2002) reported that seed yield and quality largely depend on the stage of maturity of crops. Shaheb et al. (2011 and 2012) reported higher seed yield of wheat from November sowing and seed yield was decreased with the delaying of sowing time. Dharmalingam and Basu (1990) reported that seed development and maturation are important because the seeds are harvested to ensure good yield associated with viability, vigour and field performance. Harvesting with high moisture content increases the chances of

${ }^{1}$ Senior Scientific Officer, On-Farm Research Division, Bangladesh Agricultural Research Institute (BARI), Sylhet-3100, 2-4Scientific Officer, Principal Scientific Officer and Chief Scientific Officer, Seed Technology Division, BARI, Gazipur-1701, Bangladesh. 
mycofloral infection on seed, while harvesting at low moisture content increases mechanical damage to seed (Yadav et al., 2005). The seed reaches its maximum dry weight at physiological maturity and should be harvested at proper time to ensure better germinability and vigour. Late sowing, higher plant population, desiccation and earlier harvesting reduces seed size of dwarf French beans, and seed germination of all treatments is $\geq 91 \%$ though significant differences are found in seed vigour (Greven et. at., 2004).

The seed quality in general does not change significantly between physiological maturity (PM) and harvest maturity (HM), but in some cases the proportion of viable seeds increases between PM and HM, especially when ambient temperatures are relatively low (Muasya et al., 2008). Thus harvesting of seed crop at optimum stage of seed maturation is essential to obtain better seed quality. The major three aspects of seed quality are a) genetic and physical maturity, b) high germination percentage and vigour, and c) freedom from seed-borne disease and insects (Seshu and Dadlani, 1989). There is hardly any literature available on seed quality studies on popular varieties of wheat sown at different times in Bangladesh. Hence, the experiment was undertaken to see the effect of sowing time and variety on the seed germination and vigour index after the harvest of wheat.

\section{Materials and Method}

Experiments were conducted in research field and laboratory of Seed Technology Division, Bangladesh Agricultural Research Institute, Gazipur during rabi season of November 2008 to April 2010. There were two sets of treatments comprising a) three dates of sowing viz. $\mathrm{S}_{1}: 20$ November, $\mathrm{S}_{2}: 5$ December and $\mathrm{S}_{3}: 20$ December; and $b$ ) three varieties viz. $\mathrm{V}_{1}$ : 'Bijoy', $\mathrm{V}_{2}$ : 'Sufi' and $\mathrm{V}_{3}$ : 'Prodip'. The field experiment was laid out in a split plot design with three replications assigning sowing time in main plot and variety in sub plot for field and completely randomized design was followed for laboratory studies. The unit plot size was $3 \mathrm{~m}$ x 5m. The land was fertilized with $92,32,23$ and $20 \mathrm{~kg} \mathrm{ha}^{-1}$ of $\mathrm{N}, \mathrm{P}, \mathrm{K}$ and $\mathrm{S}$, respectively. One-third of $\mathrm{N}$ and all other fertilizers were applied at final land preparation. Seeds were sown in furrows at the rate of $120 \mathrm{~kg} \mathrm{ha}^{-1}$ in $20 \mathrm{~cm}$ apart rows. The two years weather data are given in Fig. 1 and 2.

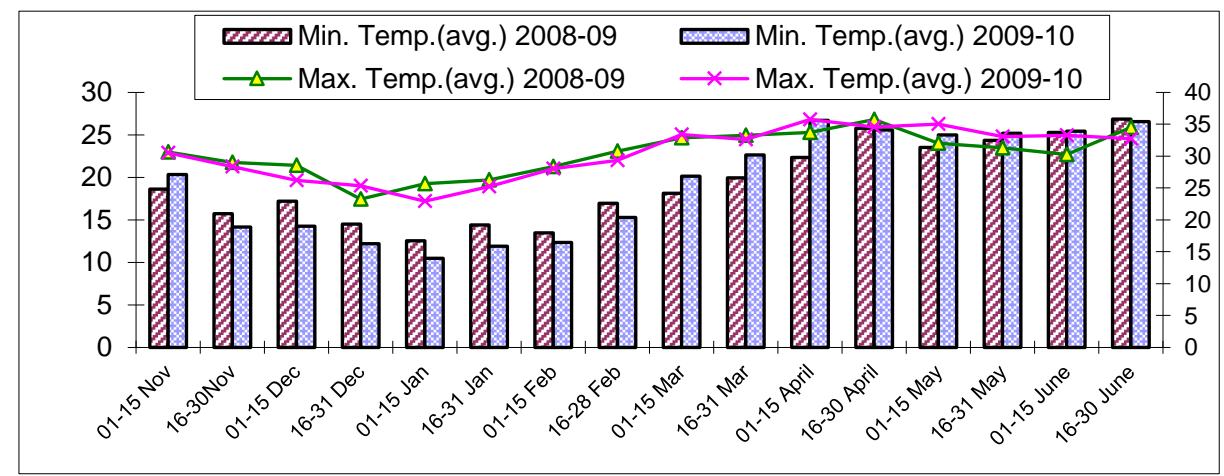

Fig. 1. Mean maximum and minimum temperature $\left({ }^{0} \mathrm{C}\right)$ data at Joydebpur, Gazipur from November to June (2008-10). 


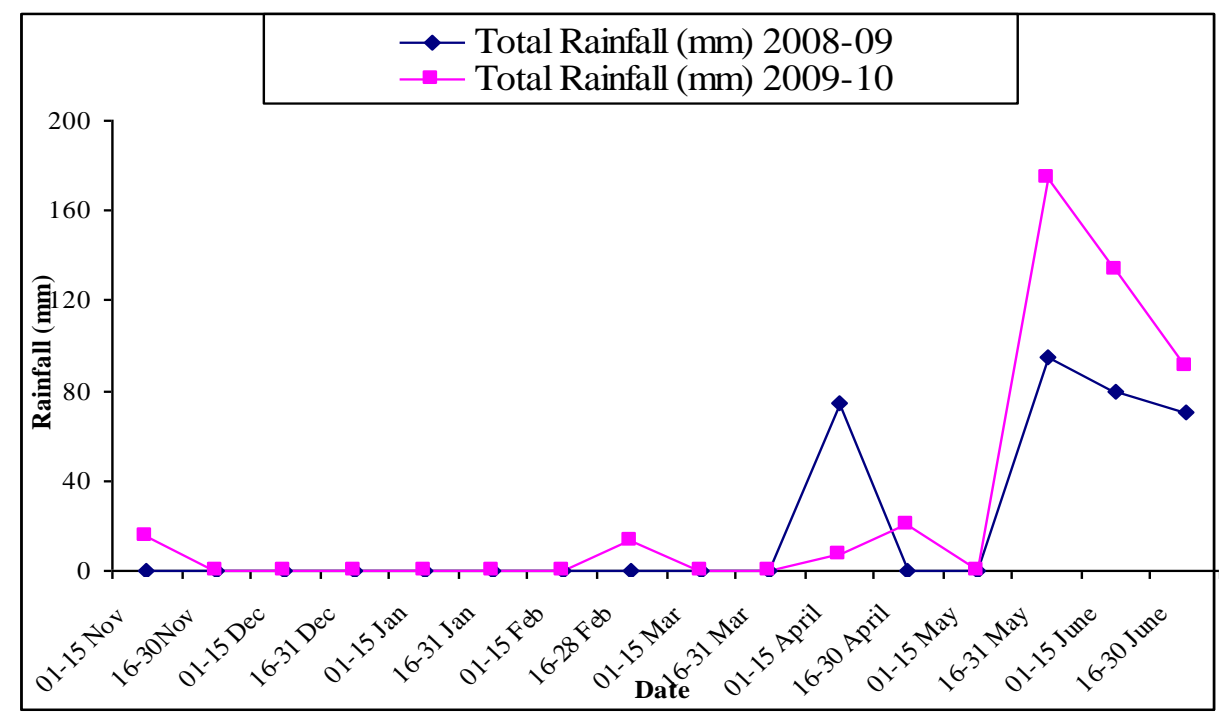

Fig. 2. Total rainfall (mm) data at Joydebpur, Gazipur from November to June (2008-10).

From the figures, it was observed that the average maximum temperatures (around $34^{\circ} \mathrm{C}$ ) were in the month April in both the years while the lowest minimum temperature was recorded in the middle of January (above $9^{\circ} \mathrm{C}$ ). There was almost no rainfall recorded during the growing period (November to February) of wheat in both the years except in the last week of February, when only $5 \mathrm{~mm}$ of precipitation was recorded. However, total rainfall ranged from $5 \mathrm{~mm}$ to well above $160 \mathrm{~mm}$.

All intercultural operations viz. weeding, thinning, irrigation and drainage were carried out as and when necessary. The wheat varieties sown on 20 November, 05 December and 20 December were harvested on 11 March, 23 March and 05 April, respectively. After threshing, seeds of each plot were sun dried and then cleaned properly. Seed quality parameters including seed vigour data of wheat varieties were recorded as per following methods:

\section{Determination of moisture content}

The moisture content (MC) of seed sample as per treatment was determined after harvest according to ISTA (1999). Ground seed samples of each treatment were taken into moisture cup and put into a pre heated oven at temperature of $103 \pm 2{ }^{\circ} \mathrm{C}$ for one hour according to Morshed et al. (2003). After cooling, the weight of the container with its cover and contents were taken. The seed samples were cooled in desiccators and weighed to work out the percent moisture content of the grains. However, the MC of all varieties harvested at different dates were brought and 
adjusted at $11.50 \%$. The seed moisture content was determined by dry weight basis and was calculated by the following formula:

$$
\text { Seed moisture content }(\%)=\frac{M_{2}-M_{3}}{M_{2}-M_{1}} \times 100
$$

Where,

$M_{1}$ is the weight in grams of the container and its cover,

$\mathrm{M}_{2}$ is the weight in grams of the container, its cover and its contents before drying

$\mathrm{M}_{3}$ is the weight in grams of the container, its cover and contents after drying.

\section{Determination of germination percentage}

The data on seed germination (\%) was taken out after harvest by the following formula (ISTA, 1999). For each treatment, 100 seeds were put into large petri dishes with four replications. The Petri-dishes were then put at room temperature $\left(25 \pm 2^{0} \mathrm{C}\right)$. After eight days, sprouted normal, abnormal and diseased seeds were counted by the following formula:

$$
\text { Seed Germination }(\%)=\frac{\text { No. of seed germinated }}{\text { Total seed }} \times 100
$$

\section{Measurement of root and shoot length}

From the eight days of seedlings, 10 plants were randomly selected. Seedlings were then cut and root and shoot parts were separated and their lengths were measured.

\section{Determination of fresh and dry weight of seedling}

After measurement of root and shoot length, fresh weight and dry weight of seedlings were recorded. Then the root and seedlings were put into paper packet and placed into the preheated oven $\left(70^{\circ} \mathrm{C} \pm 2^{\circ} \mathrm{C}\right)$ for 48 hours. After cooling in desiccators, the dry weights were taken.

\section{Determination of vigour index}

Seed vigour index was calculated and determined by multiplying germination (\%) and seedling dry weight according to Abdul-Baki and Anderson (1973) and Reddy and Khan (2001).

Vigour index $(\mathrm{VI})=\mathrm{PG} \times \mathrm{SDW}$

Where,

$V I=$ Vigour index;

$P G=$ Percent germination of seed, and

SDW = Seedling dry weight (Average) 
The collected data were analyzed statistically following the ANOVA technique with the help of MSTAT-C software. The mean differences among the treatment means were done by Least Significant Difference (LSD) test (Gomez and Gomez, 1984).

\section{Results and Discussion}

Results obtained from the two consecutive years of 2008-09 and 2009-10 were presented in Tables 1-3.

\section{Effect of sowing time on the seed quality of wheat}

Significant variations were observed due to different sowing time on the seed quality of wheat viz. shoot length and vigour index for both 2008-09 and 2009-10 and only in root length of seedling in 2008-09, though the others were not significant (Table 1). It revealed that the highest shoot lengths (11.88 and 12.95 $\mathrm{cm}$ ) were found from 20 December sowing during the year 2008-09 and 2009-10, respectively while the lowest shoot lengths $(11.11$ and $11.70 \mathrm{~cm})$ were recorded from 20 November sowing. The highest seed vigour indices, 1.38 and 1.30, were recorded in 20 November and 05 December sowing from the year 2008-09 and 2009-2010, respectively and the lowest seed vigour indices, 1.15 and 1.02, were observed from 20 December sowing in 2008-09 and 2009-10, respectively.

\section{Effect of variety on the seed quality of wheat}

Wheat varieties showed significant differences on the seed quality of wheat viz. seedling root and shoot length in 2008-09 and 2009-10 and seed germination and vigour index only for the year 2008-09 and the other characters were not significant (Table 2). In 2008-09, the highest seed germination (92.44\%) was found from the variety 'Sufi' and the lowest $(87.78 \%)$ was found in the variety 'Bijoy'. The highest seedling root lengths $(11.99$ and $12.13 \mathrm{~cm})$ were observed in variety 'Prodip' and 'Sufi' in 2008-09 and 2009-2010, respectively while the lowest seedling root lengths $(10.71$ and $10.48 \mathrm{~cm})$ were found in the variety 'Bijoy' both from the years, respectively. The highest shoot lengths $(11.79$ and $13.16 \mathrm{~cm})$ were observed in the variety 'Prodip' and 'Bijoy', respectively and the lowest shoot lengths $(10.94$ and $11.64 \mathrm{~cm})$ were found in variety 'Bijoy' and 'Sufi' in the year 2008-09 and 2009-2010, respectively. However, in 2008-09, the highest vigour index (1.44) was found in the variety 'Sufi' and the lowest vigour index (1.19) was obtained in variety Prodip, respectively (Table 2).

\section{Combined effect of sowing time and variety on the seed quality of wheat}

It was observed that seed germination, root and shoot lengths, root-shoot ratio and vigour index of wheat were significantly affected by sowing time and variety though the other parameters were not significant (Table 3). The highest seed germination $(93.33 \%)$ and shoot length $(12.23 \mathrm{~cm})$ were recorded in the treatment 


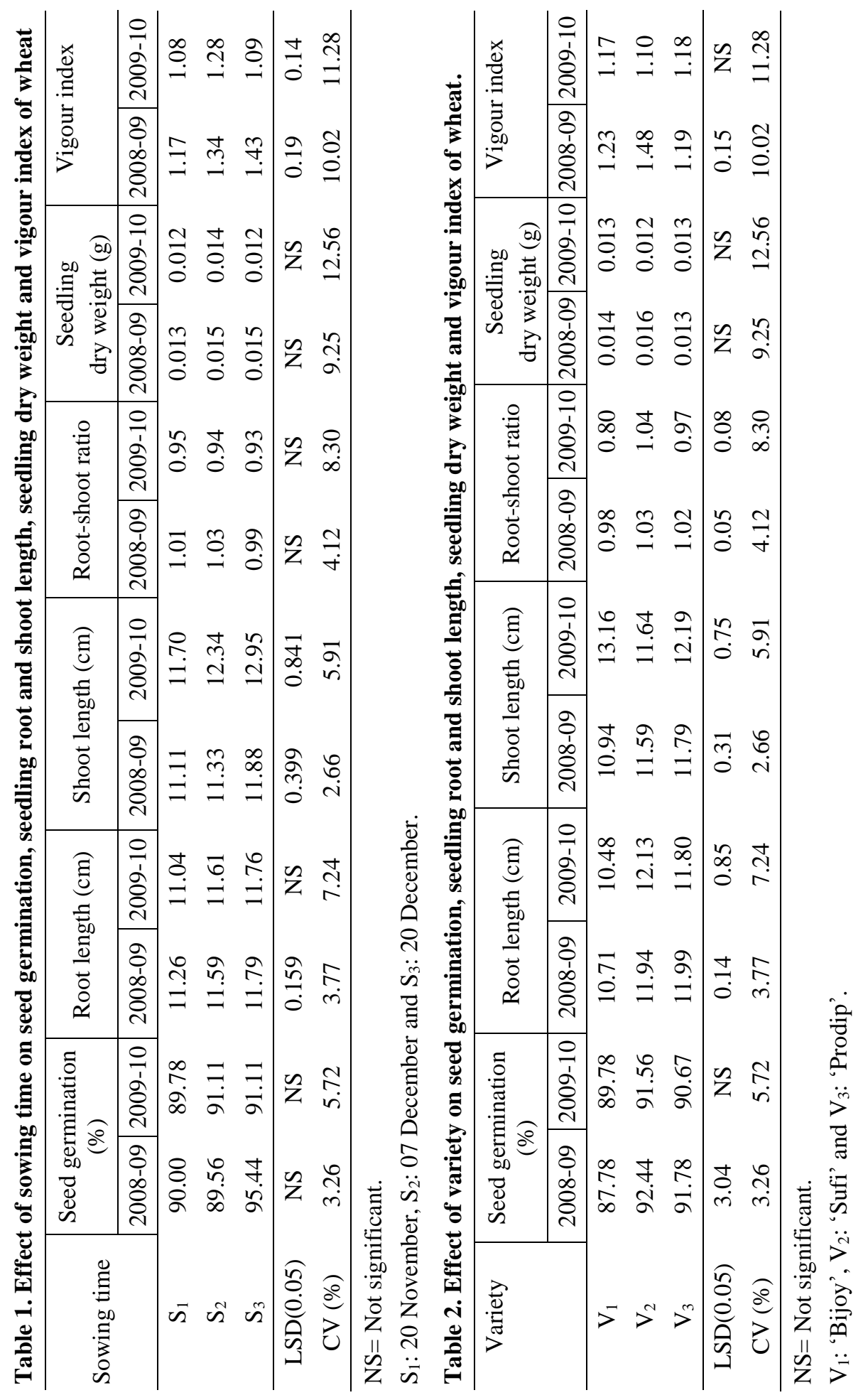




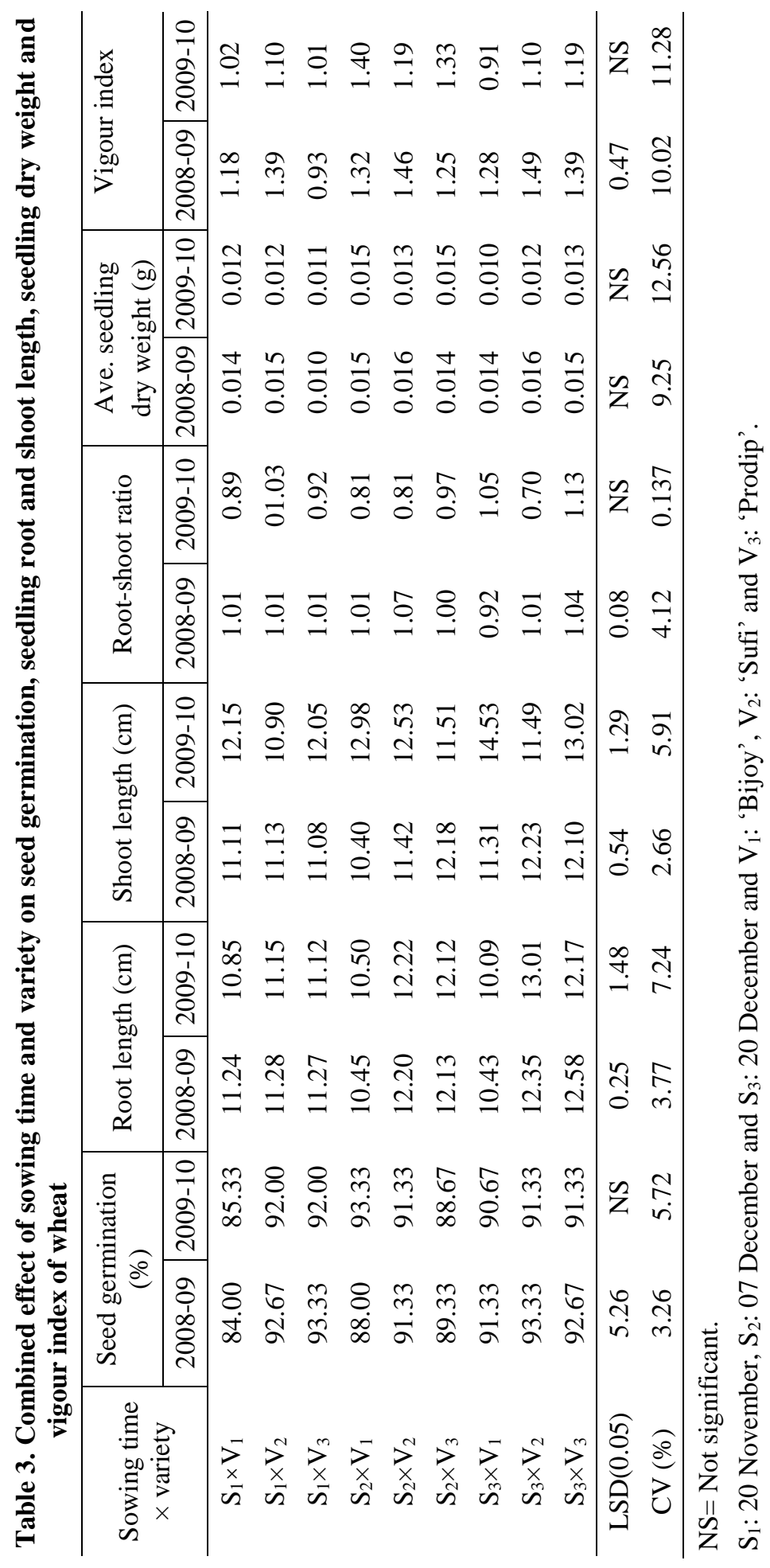


combination $\mathrm{S}_{3} \times \mathrm{V}_{2}$ and the lowest was found from the treatment combination $S_{1} \times V_{1}$ and $S_{1} \times V_{3}$, respectively in 2008-09 while in 2009-10, these values were recorded higher $(93.33 \%$ and $14.53 \mathrm{~cm})$ in the treatment combination of $\mathrm{S}_{2} \times \mathrm{V}_{1}$ and $\mathrm{S}_{3} \times \mathrm{V}_{1}$, respectively. The lowest values of seed germination $(85.33 \%)$ and shoot length $(10.90 \mathrm{~cm})$ were obtained in the treatment combination $\mathrm{S}_{1} \times \mathrm{V}_{2}$. The highest seedling root lengths $(12.58$ and $13.01 \mathrm{~cm})$ were observed in $\mathrm{S}_{3} \times \mathrm{V}_{3}$ and $\mathrm{S}_{3} \times \mathrm{V}_{2}$ in the year 2008-09 and 2009-10, respectively and the lowest values (10.43 and 10.09 $\mathrm{cm}$ ) were recorded in $\mathrm{S}_{3} \times \mathrm{V}_{1}$ treatment combination, respectively in both the years. In case of vigour index, the variety 'Sufi' sown on 20 November showed the highest vigour indices (1.53 and 1.41) in the year 2008-09 and 2009-10, respectively. The lowest values of vigour indices ( 0.96 and 0.95$)$ were recorded from the treatment combinations $\mathrm{S}_{1} \times \mathrm{V}_{3}$ (the variety 'Prodip' sown on 20 November) and $\mathrm{S}_{3} \times \mathrm{V}_{1}$ (the variety 'Prodip' sown on 20 December) during the year 2008-09 and 2009-10, respectively. The seed lot showing higher seed vigour index is considered to be more vigorous (Abdul-Baki and Anderson, 1973). The results are in agreement with the findings of Ayyub et al. (2007) who reported that physiologically mature seeds displayed better viability and seed quality. The results are also in line with the findings of Seshu and Dadlani (1989) who asserted that high germination percentage and vigour are significant aspects of seed quality. Quality seed with higher germination percentage and vigour index might be contributed to get optimum plant population, growth and development. This was also supported by Parera and Cantliffe (1994) who reported that rapid and uniform field emergence is essential to achieve better growth and high yield. Findings of previous works also showed that variation in seed germination and vigour were observed due to variation in sowing date (Tekrony et al., 1997 and Rahman et al., 2005). Adam et al. (1989) reported that early sowing of seed was associated with more yield and higher seed quality than late sowing in Ohio, USA. Similar findings were also reported in soybean by Rahman et al. (2013) who observed that germination percentage and vigour index of seed decreased with delayed sowing.

\section{Conclusion}

The present investigation revealed that most of the seed quality parameters were significantly influenced by date of sowing and variety. The highest seed germination $93.33 \%$ was recorded in the seeds of 'Prodip' variety sown on 20 December 2008, and 'Bijoy' variety sown on 5 December 2009, respectively. However, all the varieties showed more than $83 \%$ seed germination at all the dates of sowing. The highest vigour indices (1.53 and 1.41) were found in the seeds of 'Sufi' variety sown on 20 November in both the years of 2008-09 and 2009-10, respectively. Although seed germination and vigour index of wheat varieties were influenced by sowing times, all the tested varieties exhibited better seed quality immediately after harvest. 


\section{References}

Abdul-Baki, A. A. and J. D. Anderson. 1973. Physiological and biochemical deterioration of seed. In: Kozlowski, T. T., (2 ${ }^{\text {nd }}$ Ed.) Seed Biology. Academic Press, New York, London. Pp. 283-315.

Adam, N. M., Jr. M. B. McDonald and P. R. Henerlong. 1989. The influence of seed position, planting and harvesting dates on soybean seed quality. Seed Sci. Technol. 17:143-152.

Ayyub, C. M., K. Ziaf., M. A. Pervez., M. A. S. Rasheed. and N. Akhtar. 2007. Effect of seed maturity and storability on viability and vigour in pea (Pisum sativum L.) seeds. In: Proc. of International symposium on prospects of Horticultural Industry in Pakistan hosted by Institute of Horticultural Sciences, University of Agriculture, Faisalabad (28-30 March 2007). Pp. 269-273.

BADC. 2012. Annual Report (2011-12). Bangladesh Agricultural Development Corporation (BADC). P.177. (http://www.badc.gov.bd/files/ar/ar11_12.pdf).

BBS. 2011. Statistical yearbook. Bangladesh Bur. Stat., Stat. Div., Minis. Plan. Govt. People's Repub. Bangladesh. P. 37.

Dharmalingam, C. and R. N. Basu. 1990. Seed development and maturation studies in mungbean. Seed Res. 6: 101-109.

Gomez, K. A. and A. A. Gomez. 1984. Statistical Procedures for Agricultural Research. $2^{\text {nd }}$ ed. John Wiley and Sons. New York. p. 194.

Greven, M. M., B. A. McKenzie., J. G. Hampton., M. J. Hill., J. R. Sedcole and G. D. Hill. 2004. Factors affecting seed quality in dwarf French bean (Phaseolus vulgaris L.) before harvest maturity. Seed Sci. Technol. 32(3): 797-811.

ISTA. 1999. International Rules for Seed Testing. Seed Science and Technology. International Seed Testing Association, Zurich, Switzerland. 27: 155-199.

Kumar, V., S. D. Shahidhan., M. B. Kurdikeri., A. S. Channaveeraswami and R. M. Hosmani. 2002. Influence of harvesting stages on seed yield and quality in paprika (Capsicum annuum L.). Seed Res. 30(1): 99-103.

Mondal, M. H. 2005. Challenges and opportunities of sustainable crop production in Bangladesh. $8^{\text {th }}$ Biennial Agronomy Convention. Bangladesh Society of Agronomy.

Morshed, M. S., M. Begum., M. A. Basher and W. Sultana. 2003. Effect of storage containers on seed quality of three pulses. Bangladesh J. Life Sc. 15(1):107-112.

Muasya, R. M., W. J. M. Lommen., C. W. Muui and P. C. Struik. 2008. How weather during development of common bean (Phaseolus vulgaris L.) affects the crop's maximum attainable seed quality. NJAS - Wageningen J. Life Sci. 56(1/2):85-100.

Parera, C. A. and D. J. Cantliffe. 1994. Pre-sowingseedpriming. Hort. 6:109-141.

Rahman, M. M., J. G. Hampton and M. J. Hill. 2005. Soybean seed yield as affected by time of sowing in a cool temperature environment. Seed Sci. Technol. 7:1-15. 
Rahman, M. M., M. M. Rahman and M. M. Hossain. 2013. Effect of sowing date on germination and vigour of Soybean (Glycine max L.) seeds. The Agrilcurists. 11(1): $67-75$.

Reddy, Y. T. N. and M. M. Khan. 2001. Effect of osmopriming on germination, seedling growth and vigour of khirni (Mimosops hexandra) seeds. Seed Res. 29 (1): 24-27.

Seshu, D. V. and M. Dadlani. 1989. Role of woman in seed management with special reference to rice. IRTP Technical Bulletin 5. Pp. 24.

Shaheb, M. R., A. Nessa. and M. A. Hossain,. 2012. Seed yield and yield contributing components of wheat as affected by sowing time and variety. Bangladesh Agron. J. 15(2): 67-73.

Shaheb, M. R., A. Nessa., M. N. Islam., M. R. Azim. and M. Saifuzzaman. 2011. Response of seeding time on the seed yield and yield contributing characters of wheat in old Himalayan piedmont plain soil. J. Bangladesh Soc. Agric. Sci. Technol., 8 (1\&2):129132.

TeKrony, D. M., D. B. Egli., R. H. Ellis., M. Black., A.J. Murdoch and T. D. Hong. 1997. Accumulation of seed vigour during development and maturation. Plant Sci. Biotech. Agric. 30:369-384.

Yadav, S. K., S. Yadav., P. R. Kumar and K. Kant. 2005. A critical overview of chickpea seed technological research. Seed Res. 33(1):1-5. 